\title{
Task Performance and Adaptive Performance Among Logistician: A Conceptual Perspective on the Individual Factors and the Situational Factors
}

\author{
Muhamad Fadzly Abd Kadir, Azni Zarina Taha \\ Department of Business Policy and Strategy, Faculty of Business and Accounting, \\ University of Malaya, Malaysia.
}

\begin{abstract}
The purpose of this paper is to propose a conceptual framework on the individual factors, situational factor and individual work performance of logistician working at the Royal Service Corps in the Malaysian Army. The current paper is intended to examine the relationship between individual and situational factors and their impact on individual work performance. Moreover, individual factors which are "openness to experience and social intelligence" and a situational factor which is "workplace relationship" have been used as independent variables. Individual ambidexterity acts as a mediating variable, while the extent of change acts as a moderating factor. The dependent variables in this study are individual work performance focusing on the dimensions of the task and adaptive performance. Theory of Work Performance and the Burke-Litwin Model are used to define concepts and explain the phenomena. It is assumed to form a significant relationship between employee capacity, willingness and opportunity towards performance and organisational environments are perceived and interpreted by their employees. Findings from this study have implication for the selection process, mixture and redeployment of personnel; training and competency development; and overall organisation improvement.
\end{abstract}

Key words: Adaptive Performance, Extent of Change, Individual Ambidexterity, Military Logistician, Openness to Experience, Social Intelligence, Task Performance, Workplace Relationship

\section{INTRODUCTION}

The importance of logistics had been numerously debated either in the military or corporate domain [1]. As a mission-driven organisation, accomplishing given mission statement is the upmost task performance required in every military personnel. In military and as well as the corporate domain, logistics task performed by the logistician is generally to achieve the essence of logistics which constitute of "7 right"; Right Product, Right Quantity, Right Quality, Right Place, Right Time, Right Costs, and Right Customer [2].

Logistician works in unpredictable and uncertainties conditions. Any intervention and changes imposed by the organisation and managerial caused changes in the work climate. Climate was defined as "an employee's interpretation of the significance of the organisational environment for personal well-being" [3]. The work climate changes have an impact on the employee, both positively and negatively [4]. Empirical studies have shown that individual reactions towards work climate change may be clustered into three categories: attitudinal, behavioural, and health-related [5]. Attitudinal reactions (i.e. job satisfaction or commitment to the organisation), influence how the employee will undertake their work tasks [6][7]. The work climate can also shape behavioural reactions, such as turnover behaviour, compliance with safety regulations, or performance [8][9]. Health-related reactions (i.e. mental health complaints and somatic symptoms) are also often related to work stress [10].

Corresponding Author: Muhamad Fadzly Abd Kadir, Faculty of Business and Accounting, University of Malaya, Malaysia. Email: fadzly@siswa.um.edu.my 
The problem is that those studies did not show the impact of individual ambidexterity and the extent of change in detail. The intervention or changes are done by the organisation influence the work climate on individual and contextual factors. It affects both task performance and adaptive performance either in the military and corporate logistics domain. Thus, the objective of this study is to conceptualise on the extent of change and develop a model that explains individual, contextual factors and ambidextrous behavior displays by the logistician. Practically, it improves task performance and adaptive performance in the context of military logistics.

\section{LITERATURE REVIEWS}

Over the past decade, job performance has been the most investigated construct by many researchers. Nevertheless, it is still relevant because of the job performance studied in multiple perspectives and different purposes [11]. Job performance may know in a various name such as Employee Performance, Work Performance, or Individual Work Performance [12]. There were several dimensions of work performance had been investigated. The evolution started with Task Performance and developed further encompassed Contextual Performance or Organisational Citizenship Behaviour (OCB), Adaptive Performance, Creative Performance and Counterproductive Performance [13]. This study is focusing on individual work performance cover on two dimensions which are task performance and adaptive performance. Those dimensions selected because of the nature of the military performing their task and the fluidity of the current battlespace. Furthermore, work performance had been identified as a multiplicative interaction between personal factor, situational factor, and work environmental factor [14] [15].

\section{Task performance}

Task performance is defined as behaviour related to the achievement of projected, specified, or formal role commitments as part of, organisational members [16]. The most relevant definition of work performance toward this study is "observable things people do (i.e., behaviours) that are relevant for the goals of the organization (p. 314)" [17]. A consistent finding has weighted task performance approximately as high as other performance (i.e. counterproductive performance) in making these judgments by the supervisor [18][19]. Campbell [16] proposed two dimensions represent task performance, (1) job-specific task proficiency and (2) non-job-specific task proficiency.
In the military domain, the North Atlantic Treaty Organisation (NATO) has revised their logistics as a 'collective logistics' to ensure the deployability and sustainability of NATO forces to meet operational needs [20]. While the People's Liberation Army (PLA) China is focusing on joint logistics which ultimately to achieve precision logistics support capability to meet its strategy [21]. Malaysian Army also required efficient Combat Service Support (CSS) [22]. CSS (i.e. logistics activities) is an important element to sustain a force in operations during a war or peacetime. Thus, the task performance of Royal Service Corps (RSC) officers and personnel are warranted.

\section{Adaptive performance}

The dynamic in the business environment has introduced a new dimension known as adaptive performance. Allworth and Hesketh performed an early attempt to understanding adaptive performance. They defined individual adaptive performance as "behaviours demonstrating the ability to cope with change and to transfer learning from one task to another as job demands vary (p. 98)" [23]. This phenomenon influenced researchers to further study on individual adaption $[24][25][26][27][28]$. A study also proposed adaptive performance not happened on individual only but at the team level as well [29].

A study in military context had developed a taxonomy for a better understanding of adaptive behavior [30]. Adaptive performance was classified as adjusting of behaviours to the requirements of work situations and new events through eight categories of behaviour; handling emergencies or crisis situations; handling work stress; solving problems creatively; dealing with uncertain and unpredictable work situations; learning work tasks, technologies, and procedures; demonstrating interpersonal adaptability; demonstrating cultural adaptability; and demonstrating physically oriented adaptability [31]. That behaviour to be conceptualised and adapted in the context of adaptive performance for this study.

\section{A conceptual perspective on the individual factors}

Performance studies on individual differences can be traced back as in the early 1970s. Morrison found predictors of self-esteem, decision making speed and simplicity, and openness to experience at adapting to change [32]. The latter study by Ramawickrama identified individuals' dimensions such as motivation, professional experiences, 
cognitive ability and personality impacted individual job performance [11].

\section{Openness to experience}

The notion of openness was theorised as an ego facilitator and introduced in literature as ego psychology [33]. Later, Schachtel changed and conceptualised as openness to experience and refers to the individual ability to approach objects of experience in a multitude of ways [34]. McCrae and Costa have described Openness to Experience as a wide-ranging construct that includes the need to "enlarge and examine experience" observed through a "breadth, depth, and permeability of consciousness (p. 2)" [35]. Individuals who have strong Openness to Experience interested in information and experience gave and kept their self-updating [36][37] (McCrae, 1994, 2007). In more recent professional literature, it has been labelled as a willingness to create alternative solutions to problems and diversity of approach [38]. Currently, Openness to Experience is recognised as one of the personality traits in the Big Five theory.

\section{Social intelligence}

Research on social intelligence has been conducted way back in the early twenty by Thorndike, as he defined social intelligence as "the ability to act wisely in human relations (p. 228)" [39]. Based on definition derived, it seems that social intelligence required focusing on three components which are psychometric, cognitive and behaviour. He conceptualised social intelligence as a psychometric aspect which divided intelligence into three sets; (1) Abstract intelligence (cognitive), as an ability to understand and practise with the verbal and symbols, (2) Social intelligence (behaviour), as an ability to comprehend people and cooperate with them, and (3) Mechanical intelligence (psychometric), as an ability based on handling with objects. Further research conducted and differentiated social intelligence from academic intelligence and proposed social intelligence in relations of behavioural outcomes [40]. Marlowe proved social intelligence better than academic intelligence in social behaviour and linked it to social competence [41]. Later, social intelligence has been realised to be related to improved social problem-solving capabilities [42], skilled leadership [43], and constructive interpersonal competency.

\section{Individual ambidexterity}

Previous literature studies on individual ambidexterity suggested that further study should be an emphasis on contextual ambidexterity which how individual achieved ambidexterity behaviour and utilised that capability towards the organisation performance [44][45][46]. In the contextual ambidexterity perspective, Good and Michel defined individual ambidexterity as the "cognitive ability to flexibly adapt within a dynamic context by appropriately shifting between exploration and exploitation (p. 437)" [47]. Most empirical studies were measuring ambidexterity as a behavioural towards performance outcomes at various levels, either organisation, team and individual [48]. At the employee level, explorative activities consist of behaviours such as searching for a new product and process innovation, searching for competitive solutions in which these behaviours require the employee to learn new skills or knowledge and require the employee to adapt to the current routines [49]. In contrast, exploitative activities consist of using present knowledge and skills to make shortterm improvements regarding efficiency and efficacy [49][50]. The lines between exploration and exploitation are not always clear [44]. As mentioned by Reimer, the RML revolution is becoming a modernisation in logistics, and it depends on the logistician to revolutionise and to rethink current logistics process (exploration activities) and integrated logistics functions with exploiting best ideas and practise (exploitation activities) [51]. Based on that nature, that process required an ambidextrous logistician that possesses a behaviour that Good and Michel conceive as divergent thinking (exploration), focused attention (exploitation), and cognitive flexibility (switching between exploration and exploitation) [47].

\section{A conceptual perspective on the situational factors}

Besides the influence of individual factors on the employee outcomes at the workplace, the importance of situational factors begun an interesting area of study [52]. These situational factors may provide an understanding of the impact of situational factors on job performance [53]. This study will be focusing on three individual and two situational factors affecting individual work performance (task and adaptive performance); openness to experience, social intelligence, and individual ambidexterity and intent to identify the influence of workplace relationship and extent of change as a situational factor.

\section{Workplace relationship}

A relationship involving a co-worker, such as manager-employee, mentoring or between peers denotes as a workplace relationship [54]. The workplace represents an individual's function in their daily lives [55], demanding the interaction of co-workers, supervisors, subordinates, and a multitude of other work-related roles. Work tasks often involve assisting co-workers, cooperating in 
teams, leading subordinates, and interacting with clients [56]. Graen and colleagues introduced LMX theory during the 1970s [57][58]. At this time, the LMX theory was referred to leadership approach in vertical-dyad-linkage (VDL) method. Meanwhile, Team-member exchange (TMX) was originally based on the social exchange theory [59]. The theory aims to capture the quality of the social exchange relationship between a focal team member and the team as a whole [60][61]. Collaboration between employees is needed for them to achieve performance which they could not accomplish on their own. This interpersonal foundation is also studied in the context team level and crossfunctional job design. [62][63]. As such, the quality of these relationships has important consequences for employee experiences, including employee information experiences. Workplace relationships function as decision-making, influence-sharing, and instrumental and emotional support systems [64][65]. Workplace relationships are exclusive interpersonal relationships with important implications for individuals in organisations where relationships exist and develop. LMX signifies a long-term partnership between manager-employee, focusing on respect and mutual trust [66]. Meanwhile, TMX relationships might assist them to overcome emotional aspects when facing new and challenging jobs [67].

\section{Extent of change}

There is a growing interest of studies to identify the effect of the organisational change on an individual employee [40]. A frequent organisational change will impact different work unit and individual [41]. Different level of the employee may also view changes differently. Senior manager view changes as an opportunity while executives and low-level manager and employee may find it unwelcome and view it as a disruption towards their routine activities [42]. Lau \& Woodman proposed extent of work unit change as deviations to or interruptions in working scopes such as work routines procedures, and processes in influencing individuals' responses [43]. Researchers had studied the impact of change processes in which they found that perceptions of the change outcomes, the extensiveness of change, and the impact of change affect the change reaction on the individual employee [44][45][46]. That is why the assessment of the extension of change in the referenced object is more important than the cause. For example, more extensive changes in a work setting (change in task conditions/procedures) reflects more difficult transitions, greater adaption, more threat and uncertainty [47]. Especially in the short notice, immediate job setting changes required alteration of abilities an employee. According to O'Reilly and Tushman, major changes in work process likely to impose re-evaluation of alignment between organisation and individual [48].

\section{Underlying theories}

In order to provide a good theoretical framework, selection right and related theory are crucial. The theory will provide understanding in term of the interaction of construct, measurements concepts, and provide insight regarding problem or phenomenon studied [68]. The development of the current research framework is adopted theories from Theory of Work Performance and Psychological Climate Theory. The context of this study to identify behaviour phenomenon of RSC officers and personnel regarding individual work performance and its influenced by the individual factors and situational factors.

\section{Theory of work performance}

A theory of work performance [15] was adopted as one of the underlying theories for this study. They built this theory based on the action-research project to increase American underground coal mine job performance. It proposed three dimensions of work performance comprises a broad range of variables identified from various literature and field observation. This theory explains the predictors that influence the work performance of an individual. It is a multiplicative interaction between personal factor, situational factor, and environment. The willingness refers to the psychological and emotional characteristics that influence the degree to which an individual is inclined to perform a task comprise [15]. The capacity refers to the physiological and cognitive capabilities that enable an individual to perform a task [15]. The opportunity referring to the particular configuration of the field of forces surrounding a person and his or her task performance and that are beyond the person's direct control and may enhance and constrain their job performance [15].

\section{Burke-Litwin Model}

The environment is one of the drivers for change. Burke-Litwin model [69] taking consideration of various change drivers and rank it according to in term of importance. The most importance situated at the top of the model and it gradually less importance along with the bottom layers. Changes in a factor affect other factors. The lower half of the BurkeLitwin model is to be considered as the one of theory to be used in this study. The lower part to be considered as a transactional factor that they proposed that changes happen within the scope of the management [69]. Each box has its definition that clarify the element of change in its purposed model. This study will be focusing on the extent of 
the change made by the organisation. Thus, the important elements that imply an employee were work unit climate, task and individual skill, individual needs and performance, motivation, and individual and organisation performance. Prediction of behaviour and performance consequences are the main objectives of the Burke-Litwin model [69]. According to Furnham and Gunter, the BurkeLitwin model is the most persuasive in the role of organisational climate in business performance [70]. It deals with cause (organisational) and effect (performance), serving as a guide not only for organisational diagnosis [71]. French and Bell, at the same time, suggested that the model is suitable for planned organisational change [71]. Kraut labels the model as comprehensive that may enhance the efficiency of organisational analysis and serve as a guide to performance [72]. Various studies provide an example of the importance of organisation climate towards employee behaviour. At the individual level, researchers have reported relationships between employees' perceptions of their work environment and outcomes such as job performance [73], job satisfaction [74], organisational citizenship behaviour [75], burnout [76], and job involvement [3].

\section{Conceptual model}

The purposed conceptual model in this study will measure the relationship between independent variables (openness to experience, social intelligence, workplace relationship) and the dependent variables (task performance and adaptive performance), as well the mediating outcomes of individual ambidexterity and moderating results of the extent of change as in Figure 1 with 19 hypotheses proposed to test these relationships.
By using the Theory of Work Performance in the context of this study, the variable used for measuring willingness dimension is the personality trait (openness to experience). Meanwhile, the variable for the capacity dimension is social intelligence. Social intelligence in this study did not encompass the dimension of cognitive ability only but including also the skill and analysing capability dimension as well. The workplace relationship is to be considered as the opportunity dimension in this study. The LMX and TMX sub-dimensional constructs are related to work environment setting, as suggested by Blumberg \& Pringle [15]. The performance will incorporate the task and adaptive performance. The mediating role of individual ambidexterity is the capacity dimension which individual required exploring knowledge and exploiting the experience of him and another employee. Borrowing the BurkeLitwin model by introducing the extent of change variable may provide an insight into the employee perceived and interpreted intervention towards the changing of work climate.

\section{CONCLUSION}

As the logistics played an important role in sustaining forces and supporting the grand strategy, the logistician behaviour is crucial to be highlighted to improve the individual performance and subsequently, the organisation as well. If employee experience changes which have a great impact on their work-routines, processes and structures, this can lead to reduced work passion and reluctance among employees, which ultimately affect their performance.

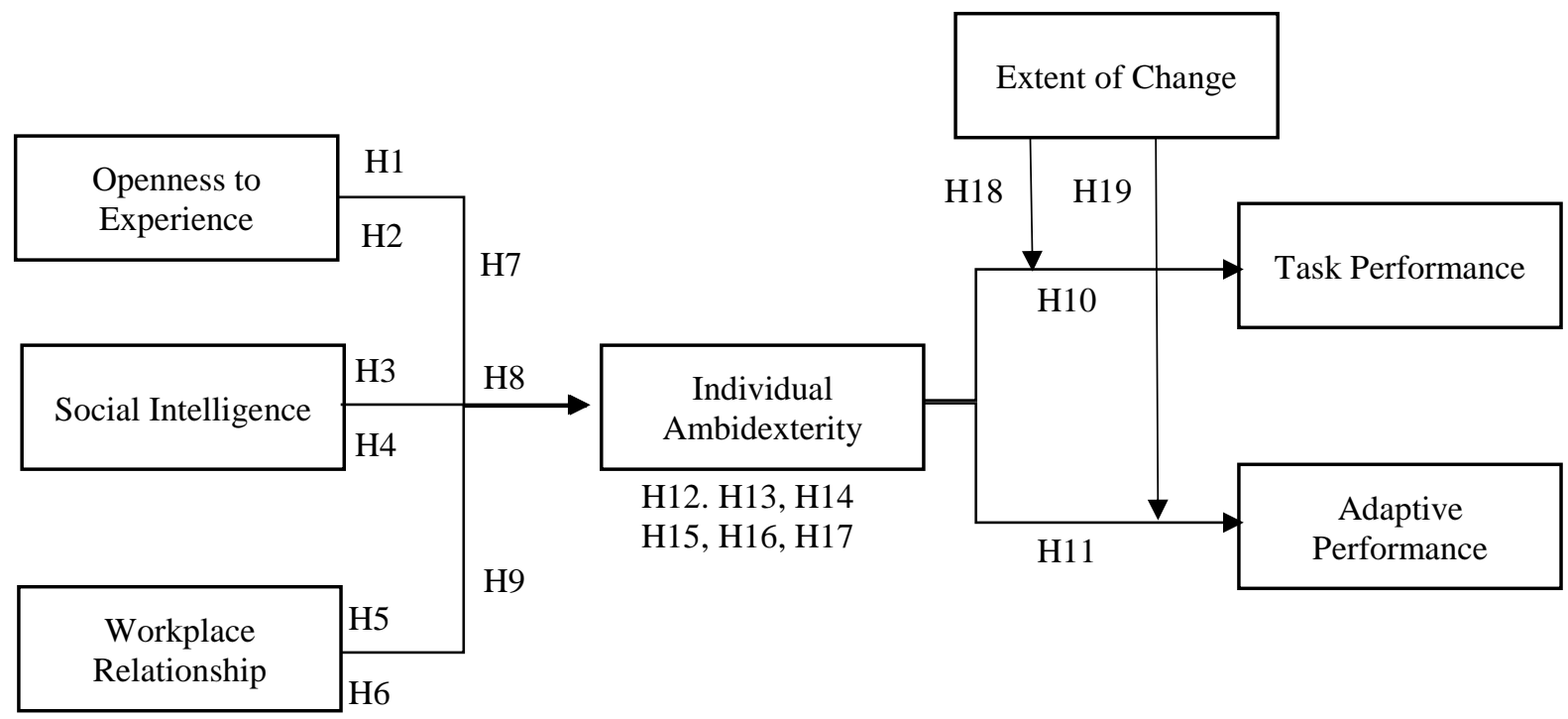

Figure 1: Conceptual model 
The results from this study have implication for the selection process, mixture and redeployment of personnel; training and competency development; and overall organisation improvement. Hence, the findings can be generalised into the population. A questionnaire has been developed, adapted from previous studies; a pilot study has been conducted, and data collection is in the process. Examples of items measurement as in Annex. Data analysis will be conducted through descriptive and inferential statistics compiling with structural equation modelling analysis.

\section{REFERENCES}

[1] Leuschner, R., Charvet, F., \& Rogers, D. S. (2013). A meta-analysis of logistics customer service. Journal of Supply Chain Management, 49(1), pp. 47-63.

[2] Gleissner, H., \& Femerling, J. C. (2013). IT in Logistics. In Logistics, Springer, Cham, pp. 189-223.

[3] Brown, S. P., \& Leigh, T. W. (1996). A new look at psychological climate and its relationship to job involvement, effort, and performance. Journal of applied psychology, 81(4), pp. 358368.

[4] Naswall, K., Hellgren, J., \& Sverke, M. (Eds.). (2008). The individual in the changing working life. Cambridge University Press.

[5] Jex, S.M. and Beehr, T. A. (1991). Emerging theoretical and methodological issues in the study of work-related stress. In K. Rowland and G. Ferries (eds.), Research in personnel and human resources management (vol. 9, pp. 311-65). Greenwich, CT: JAI Press.

[6] Allen, N. J. and Meyer, J. P. (1990). The measurement and antecedents of affective, continuance and normative commitment to the organization. Journal of Occupational Psychology, 63, pp. 1-18.

[7] Locke, E. A. (1976). The nature and causes of job satisfaction. In M. Dunnette (ed.), Handbook of industrial and organizational psychology (pp. 1297-349). Chicago: Rand McNally.

[8] Probst, T. M. and Brubaker, T. L. (2001). The effects of job insecurity on employee safety outcomes: cross-sectional and longitudinal explorations. Journal of Occupational Health Psychology, 6, pp. 139-59.

[9] Steel, R. P. and Ovalle, N. K. (1984). A review and meta-analysis of research on the relationship between behavioral intentions and employee turnover. Journal of Applied Psychology, 69, pp 673-86.

[10] Spector, P. E. (2000). A control theory of the job stress process. In C. L. Cooper (ed.), Theories of organizational stress (pp. 153-69). Oxford: Oxford University Press.

[11] Fogaça, N., Rego, M. C. B., Melo, M. C. C., Armond, L. P., \& Coelho Jr, F. A. (2018). Job Performance Analysis: Scientific Studies in the Main Journals of Management and Psychology from 2006 to 2015. Performance Improvement Quarterly, 30(4), pp. 231-247.

[12] Ramawickrama, J., Opatha, H. H. D. N. P., \& PushpaKumari, D. (2017). A Synthesis towards the Construct of Job Performance. International Business Research, 10(10), pp. 66.

[13] Koopmans, L., Bernaards, C. M., Hildebrandt, V. H., Schaufeli, W. B., De Vet Henrica, C. W., \& Van Der Beek, A. J. (2011). Conceptual frameworks of individual work performance: A systematic review. Journal of Occupational and Environmental Medicine, 53(8), pp. 856866.

[14] Lewin, K. (1939). Field theory and experiment in social psychology: Concepts and methods. American journal of sociology, 44(6), pp. 868896.

[15] Blumberg, M., \& Pringle, C. D. (1982). The Missing Opportunity in Organizational Research: Some Implications for a Theory of Work Performance. Academy of Management Review. 7(4), pp. 560-569.

[16] Campbell, J. P. (1990). Modeling the performance prediction problem in industrial and organizational psychology. In Handbook of Industrial and Organizational Psychology (pp. 687-732).

[17] Campbell, J. P., McHenry, J. J., \& Wise, L. L. (1990). Modeling job performance in a population of jobs. Personnel Psychology, 43(2), pp. 313-575.

[18] Borman, W. C., \& Motowidlo, S. J. (1997). Task performance and contextual performance: The meaning for personnel selection research. Human performance, 10(2), pp. 99-109.

[19] Johnson, J. W. (2001). The relative importance of task and contextual performance dimensions to supervisor judgments of overall 
performance. Journal of applied psychology, 86(5), p. 984.

[20] NATO (2012) Logistics Handbook.

[21] China's State Council Information Office, China's Military Strategy, May 2014, Beijing. http://eng.mod.gov.cn/Database/WhitePapers/ 2014.htm.

[22] Army Training \& Doctrine Headquarters. (2004). Manual of Combat Service Support, MD 4.1 TD.

[23] Allworth, E., \& Hesketh, B. (1999). Constructoriented Biodata: Capturing Change-related and Contextually Relevant Future Performance. International Journal of Selection and Assessment, 7(2), pp. 97-111.

[24] Baard, S. K., Rench, T. A., \& Kozlowski, S. W. J. (2014). Performance Adaptation: A Theoretical Integration and Review. Journal of Management, 40(1).

[25] Le Pine, J. A., Colquitt, J. A., \& Erez, A. (2000). Adaptability to changing task contexts: Effects of general cognitive ability, conscientiousness, and openness to experience. Personnel Psychology, 53(3), pp. 563-593.

[26] Cronshaw, S. F., \& Jethmalani, S. (2005). The structure of workplace adaptive skill in a career inexperienced group. Journal of Vocational Behavior, 66(1), pp. 45-65.

[27] Jundt, D. K., Shoss, M. K., \& Huang, J. L. (2015). Individual adaptive performance in organizations: A review. Journal of Organizational Behavior, 36(S1), pp. S53-S71.

[28] Polyhart, R., \& Bliese, P. (2006). Individual Adaptability (I-Adapt) Theory: Conceptualizing the Antecedents, Consequences, And Measurement of Individual Differences In Adaptability. Advances in Human Performance and Cognitive Engineering Research, 6, pp. 3-39.

[29] Han, T. Y., \& Williams, K. J. (2008). Multilevel investigation of adaptive performance: Individual-and team-level relationships. Group \& Organization Management, 33(6), pp. 657684.

[30] Pulakos, E. D., Arad, S., Donovan, M. A., \& Plamondon, K. E. (2000). Adaptability in the workplace: Development of a taxonomy of adaptive performance. Journal of Applied Psychology, 85(4), pp. 612-624.

[31] Pulakos, E. D., Schmitt, N., Dorsey, D. W., Arad, S., Hedge, J. W. and Barman, W. C. (2002) 'Predicting adaptive performance:
Further tests of a model of adaptability', Human Performance, 15: pp. 299-323.

[32] Morrison, R. F. (1977). Career adaptivity: the effective adaptation of managers to changing role demands. Journal of Applied Psychology, 62(5), pp. 549-558.

[33] Kris, E. (1952). Psychoanalytic explorations in art. New York: International Universities Press.

[34] Schachtel, E. (1959). Metamorphosis. New York: Basic Books.

[35] McCrae, R., \& Costa, P. (1997). Personality Trait Structure as a Human Universal* 1,*2. American Psychologist, 52(5), pp. 509-516.

[36] McCrae, R. R. (1994). Openness to Experience: Expanding the boundaries of Factor V. European Journal of Personality, 8(4), pp. 251272.

[37] McCrae, R. R. (2007). Aesthetic chills as a universal marker of openness to experience. Motivation and Emotion, 31(1), pp. 5-11.

[38] Huang, P., Urbana, N. M. A., He, X., Gao, J., Deng, L., Acero, A., \& Heck, L. (2013). Learning Deep Structured Semantic Models for Web Search using Clickthrough Data. The 22nd ACM International Conference on Conference on Information \& Knowledge Management, pp. 2333-2338.

[39] Thorndike, E. L. (1920). Intelligence and its uses. The Harpers Monthly, XI, pp. 227-235.

[40] Ford, M. E., \& Tisak, M. S. (1983). A further search for social intelligence. Journal of Educational Psychology, 75(2), pp. 196-206.

[41] Marlowe, H. A. (1986). Social Intelligence. Evidence for Multidimensionality and Construct Independence. Journal of Educational Psychology, 78(1), pp. 52-58.

[42] Jones, K., \& Day, J. D. (1997). Discrimination of two aspects of cognitive-social intelligence from academic intelligence. Journal of educational psychology, 89(3), p. 486.

[43] Kobe, L. M., Reiter-Palmon, R., \& Rickers, J. D. (2001). Self-reported leadership experiences in relation to inventoried social and emotional intelligence. Current Psychology, 20(2), pp. 154-163.

[44] Lavie, D., Stettner, U., \& Tushman, M. L. (2010). Exploration and exploitation within and across organizations. Academy of Management Annals, 4(1), pp. 109-155.

[45] Raisch, S., \& Birkinshaw, J. (2008). Organizational ambidexterity: Antecedents, 
outcomes, and moderators. Journal of Management, 34(3), pp. 375-409.

[46] Turner, N., Swart, J., \& Maylor, H. (2013). Mechanisms for managing ambidexterity: A review and research agenda. International Journal of Management Reviews, 15(3), pp. 317-332.

[47] Good, D., \& Michel, E. J. (2013). Individual ambidexterity: Exploring and exploiting in dynamic contexts. Journal of Psychology: Interdisciplinary and Applied, 147(5), pp. 435453.

[48] He, Z.-L., \& Wong, P.-K. (2004). Exploration vs Exploitation: An Empirical Test of the Ambidexterity Hypothesis. Organization Science, 15(4), pp. 481-494.

[49] Gibson, C. C. B., \& Birkinshaw, J. (2004). The antecedents, consequences, and mediating role of organizational ambidexterity. The Academy of Management Journal, 47(2), pp. 209-226.

[50] Kang, S.-C., \& Snell, S. A. (2009). Intellectual Capital Architectures and Ambidextrous Learning: A Framework for Human Resource Management. Journal of Management Studies, 46(1), pp. 65-92.

[51] Reimer, D.J (1999), 'The Revolution in Military Logistics', Army Logistician 31, (1).

[52] Kacmar, K. M., Collins, B. J., Harris, K. J., \& Judge, T. A. (2009). Core self-evaluations and job performance: The role of the perceived work environment. Journal of Applied Psychology, 94, pp. 1572-1580.

[53] Lee, J., Yun, S. \& Kim, S. (2017), "Consideration of future consequence and task performance: The moderating effects of support", Journal of Managerial Psychology, Vol. 32 No. 7, pp. 497-512.

[54] Sias, P. M. (2008). Organizing relationships: Traditional and emerging perspectives on workplace relationships. Sage.

[55] Dutton, J. E., \& Ragins, B. R. (2007). LEA's organization and management series. Exploring positive relationships at work: Building a theoretical and research foundation. Mahwah, NJ, US: Lawrence Erlbaum Associates Publishers.

[56] McCall, M. W., J., Lombardo, M. M., \& Morrison, A. M. (1988). The lessons of experience: How successful executives develop on the job. Lexington, MA: Lexington Books.
[57] Dansereau, F., Graen, G., \& Haga, W. J. (1975). A vertical dyad linkage approach to leadership within formal organizations. A longitudinal investigation of the role making process. Organizational Behavior and Human Performance, 13(1), pp. 46-78.

[58] Graen, G. B., \& Cashman, J. (1975). A rolemaking model of leadership in formal organizations: A developmental approach. In J. G. Hunt \& L. L. Larson (Eds.), Leadership Frontiers (pp. 143-166). Kent, OH: Kent State University Press.

[59] Blau, P. M. (1964). Justice in Social Exchange. Sociological Inquiry, 34(2), pp. 193-206.

[60] Seers, A. (1989). Team-member exchange quality: A new construct for role-making research. Organizational Behavior and Human Decision Processes, 43(1), pp. 118-135.

[61] Seers, A., Petty, M. M., \& Cashman, J. F. (1995). Team-Member Exchange Under Team and Traditional Management: A naturally occurring quasi-experiment. Group \& Organization Management, 20(1), pp. 18-38.

[62] Chen, G., Kanfer, R., DeShon, R. P., Mathieu, J. E., \& Kozlowski, S. W. J. (2009). The motivating potential of teams: Test and extension of Chen and Kanfer's (2006) crosslevel model of motivation in teams. Organizational Behavior and Human Decision Processes, 110(1), pp. 45-55.

[63] Kozlowski, S. W. J. J., \& Ilgen, D. R. (2006). Enhancing the Effectiveness of Work Groups and Teams. Psychological Science in the Public Interest, 7(3), pp. 77-124.

[64] Kram, K. E., \& Isabella, L. A. (1985). Mentoring Alternatives: The Role of Peer Relationships in Career Development. Academy of Management Journal, 28(1), pp. 110-132.

[65] Rawlins, W. K. (1994). Being there and growing apart: Sustaining friendship during adulthood. In D. J. Canary \& L. Stafford (Eds.), Communication and relational maintenance (pp. 273-292). San Diego, CA: Praeger Publishers.

[66] Graen, G. B., \& Uhl-Bien, M. (1995). Relationship-based approach to leadership: Development of leader-member exchange (LMX) theory of leadership over 25 years: Applying a multi-level multi-domain perspective. The leadership quarterly, 6(2), pp. 219-247. 
[67] Liao, H. U. I., Liu, D., \& Loi, R. (2010). Looking at Both Sides of The Social Exchange Coin: A Social Cognitive Perspective on The Joint Effects of Relationship Quality and Differentiation on Creativity. The Academy of Management Journal, 53(5), pp. 1090-1109.

[68] Imenda, S. (2014). Is There a Conceptual Difference Between Conceptual and Theoretical Frameworks? Journal of Social Science, 38(2), pp. 185-195

[69] Burke \& Litwin, 'A Causal Model of Organisation Performance and Change', Journal of Management, Vol 18, No 3 (1992), pp 523-545.

[70] Furnham, A. F. \& Gunter, B. (1993). Corporate assessment: Auditing a company's personality. London: Routledge, 1993. 293 p. ISBN 04150-8118-1.

[71] French, W. and C. Bell (1999). Organization Development: Behavioral Science Interventions for Organizational Improvement (6th ed.). New York: Prentice Hall.
[72] Kraut, A.I. (1996). Organizational surveys: Tools for assessment and change. San Francisco: Jossey Bass.

[73] Pritchard, R. D., \& Karasick, B. W. (1973). The effects of organizational climate on managerial job performance and job satisfaction. Organizational behavior and human performance, 9(1), pp. 126-146.

[74] Schneider, B., \& Snyder, R. A. (1975). Some relationships between job satisfaction and organization climate. Journal of applied psychology, 60(3), p. 318.

[75] Moorman, R. H. (1991). Relationship between organizational justice and organizational citizenship behaviors: Do fairness perceptions influence employee citizenship?. Journal of applied psychology, 76(6), p. 845.

[76] McIntosh, D. N. (1995). Religion-as-schema, with implications for the relation between religion and coping. The International Journal for the Psychology of Religion, 5(1), pp. 1-16. 
APPENDIX

ITEMS AND SCALE SOURCE

\begin{tabular}{|c|l|c|}
\hline Dimension(s) & \multicolumn{1}{|c|}{ Items } & Source \\
\hline Openness to Experience & $\begin{array}{l}\text { I see Myself as Someone Who... Is original, comes up } \\
\text { with new ideas. }\end{array}$ & $\begin{array}{c}\text { Benet-Martinez and } \\
\text { John (1998) }\end{array}$ \\
\hline Social Intelligence & I can predict other peoples' behaviour. & $\begin{array}{c}\text { Silvera, Martinussen } \\
\text { and Dahl (2001) }\end{array}$ \\
\hline Workplace Relationship & $\begin{array}{l}\text { I know where I stand. I usually know how satisfied my } \\
\text { supervisor is with what I do. }\end{array}$ & $\begin{array}{c}\text { Lee, A. P., Teng, H. Y., } \\
\text { \& Chen, C. Y. (2015). }\end{array}$ \\
\hline $\begin{array}{c}\text { Individual } \\
\text { Ambidexterity }\end{array}$ & $\begin{array}{l}\text { To what extent did you, last year, engage in work related } \\
\text { activities that can be characterized as follows: Searching } \\
\text { for new possibilities with respect to products/ services, } \\
\text { processes, or markets }\end{array}$ & $\begin{array}{c}\text { Mom, Van den Bosh, } \\
\text { and Volberda (2007) }\end{array}$ \\
\hline Extent of Change & $\begin{array}{l}\text { This specific change involved changes in the work unit's } \\
\text { processes and procedures. }\end{array}$ & $\begin{array}{c}\text { Caldwell, Herold, \& } \\
\text { Fedor (2004) }\end{array}$ \\
\hline Task Performance & $\begin{array}{l}\text { In the past 3 months, I was able to plan my work so that I } \\
\text { finish it on time. }\end{array}$ & \begin{tabular}{c} 
Koopmans et al. (2016) \\
\hline Adaptive Performance
\end{tabular} \\
\hline $\begin{array}{l}\text { I am able to achieve total focus on the situation to act } \\
\text { quickly. }\end{array}$ & $\begin{array}{c}\text { Charbonnier-voirin \& } \\
\text { Roussel (2012) }\end{array}$ \\
\hline
\end{tabular}

